\title{
LEX PETROLEA JAKO AUTONOMICZNY REŻIM PRAWNY PRAWA MIĘDZYNARODOWEGO
}

\section{WSTĘP}

Dorobek doktryny krajowej i międzynarodowej, rozwój ustawodawstw krajowych regulujących sektor energetyczny, umowy naftowe, orzecznictwo, a także praktyka podmiotów funkcjonujących w przemyśle naftowym doprowadziły do wykształcenia się szczególnego reżimu zwanego lex petrolea. Stało się tak dzięki temu, że specyfika tego sektora, jak również procesy internacjonalizacji oraz rozwiązania partykularnych problemów są globalnie bardzo podobne i podążają raczej za trendami międzynarodowymi niż krajowymi ${ }^{1}$. Dyskusja ontologiczna nad reżimem regulujaccym stany fatyczne z zakresu prawa ropy naftowej została zapoczątkowana w 1998 r. przez Doaka Bishopa, który po 25 latach badań nad orzecznictwem arbitrażowym uznał, że nie doszło jeszcze do wyodrębnienia dojrzałego systemu regulacji prawnych, a jedynie do rozwoju początków lex petrolea ${ }^{2}$. Doktryna światowa nadal boryka się z brakiem powszechnej zgody co do uznania bądź nieuznania lex petrolea za odrębny reżim prawny. Rozważania nad jego istotą i charakterem zostały wprawdzie ponownie podjęte w ostatnim czasie ${ }^{3}$, jednak nadal brak w nich ostatecznych konkluzji, co wynika z jednej strony z niejasności dotyczacych statusu lex petrolea, a $\mathrm{z}$ drugiej $-\mathrm{z}$ braku jednolitości w stosowaniu terminu self-contained regime i obaw przed fragmentacją prawa międzynarodowego.

${ }^{1}$ K. Talus, S. Looper, S. Otillar, Lex petrolea and the internationalization of petroleum agreements: focus on Host Government Contracts, „Journal of World Energy Law and Business” 5(3), 2012 , s. 181.

2 „This has not yet created a mature set of legal regulations, but it has developed the beginnings of a lex petrolea that serves to instruct, and in a certain sense even regulate - within broadly-defined boundaries - the international petroleum industry. As international arbitration continues to grow (provided that the publication of awards also continues), this lex petrolea may yet mature into a fully-developed subset of international law", R. D. Bishop, International arbitration of petroleum disputes: the development of a lex petrolea, „Yearbook Commercial Arbitration" 23, 1998, s. 1131 i n.

${ }^{3}$ Zob. przede wszystkim T. Childs, Update on lex petrolea: the continuing development of customary law relating to international oil and gas exploration and development, ,Journal of World Energy Law \& Business" 4(3), 2011, s. 214-259. W artykule autor opisuje szereg orzeczeń sądów arbitrażowych zapadłych od 1998 r. i wysuwa wniosek, że nowsze orzeczenia obejmują wystarczająco szerokie spektrum, aby utworzyć lex petrolea lub prawo zwyczajowe obejmujące normy prawne zaadaptowane dla potrzeb natury i specyfiki przemysłu naftowego. 
Celem niniejszego artykułu jest uporządkowanie przedmiotowej wiedzy w drodze analizy dorobku doktryny prawa międzynarodowego, umów zawieranych dla umożliwienia dokonywania czynności w sektorze naftowym, relewantnych orzeczeń sądów arbitrażowych i praktyki działania zaangażowanych podmiotów. W ten sposób ustalona zostanie istota lex petrolea oraz kształt normatywny tego reżimu, a wynik analizy zostaną porównane z poszczególnymi założeniami przyjętymi w Raporcie Grupy Roboczej Komisji Prawa Międzynarodowego ${ }^{4}$, zawierającym propozycję kryteriów uznania grupy norm dotyczących szczególnego zakresu merytorycznego za self-contained regime i stosowania jej jako lex specialis. Synteza zebranych informacji pozwoli na sformułowanie wniosków weryfikujących hipotezę, że lex petrolea stanowi autonomiczny reżim prawny (self-contained regime).

\section{ISTOTA LEX PETROLEA}

Termin lexpetrolea został sformułowany na gruncie wyroku z 1982 r. w sprawie Kuwejt v. Aminoil ${ }^{5}$. Strona państwowa posłużyła się nim w swojej argumentacji dotyczącej zastosowania norm zwyczajowych do wyceny wysokości szkody odniesionej w związku z niewykonaniem umowy. Proponowana koncepcja została wprawdzie odrzucona przez sąd arbitrażowy, jednak w dyskusji, która toczyła się na kanwie tego orzeczenia, zaakceptowano istnienie szczególnego reżimu lex petrolea, ukształtowanego zarówno na płaszczyźnie krajowej, jak i międzynarodowej przez legislację krajową oraz specyficzne umowy host government contracts i praktykę podmiotów przemysłu naftowego wyrażająca się we wzorcach zawieranych przez nie umów. Część autorów uważa ten reżim za szczególny odłam lex mercatoria sensu largo, obejmujący problematykę transakcji naftowych ${ }^{6}$. Niekiedy jednak doktryna odmawia temu reżimowi przynależności do lex mercatoria, gdyż - inaczej niż w przypadku lex mercatoria - lex petrolea charakteryzuje się obecnościa podmiotów państwowych $\mathrm{w}$ obrocie prawnym ${ }^{7}$.

\footnotetext{
${ }^{4}$ International Law Commission, Report on the work of its fifty-eighth session (1 May to 9 June and 3 July to 11 August 2006), Chapter XII: „Fragmentation of international law: difficulties arising from the diversification and expansion of international law", General Assembly, Official Records, Sixty-first Session, supl. nr 10 (A/61/10), http://legal.un.org/ilc/reports/2006/2006report. htm [dostęp: 31.07.2014].

${ }^{5}$ „[...] a particular rule, of an international and customary character, specific to the oil industry. [...] a customary rule valid for the oil industry - a lex petrolea that was in some sort a particular branch of a general universal lex mercatoria", Rzqd Kuwejtu v. American Independent Oil Company (Aminoil), orzeczenie z 24 marca 1982 r., „International Legal Materials” (21), 1976, s. 976, http://www.trans-lex.org/261900 [dostęp: 15.09.2014].

${ }^{6}$ Zob. szerzej odnośnie do relacji do lex mercatoria: A. de Jesús, The prodigious story of the lex petrolea and the Rhinoceros. Philosophical aspects of the transnational legal order of the Petroleum Society, „TPLI Series on Transnational Petroleum Law” 2012, nr 1, s. 18 n.

${ }^{7}$ Za: C. O. García-Castrillón, Reflections on the law applicable to international oil contracts, „The Journal of World Energy Law \& Business” 2013, nr 14, s. 12 n. Przeciwko: T. Wälde, International Standards: A Professional Challenge for Natural Resources and Energy Lawyers,
} 
Lex petrolea jest reżimem o charakterze globalnym, wymykającym się koncepcji państw narodowych i odrzucającym stosowanie norm prawa krajowego do międzynarodowych umów naftowych poprzez system norm kolizyjnych. Uczestnicy międzynarodowego przemysłu naftowego dzięki praktyce, standaryzacji specyficznych modeli umów oraz w oparciu o orzecznictwo sądów arbitrażowych tworzą normy dotyczace zarządzania międzynarodowymi umowami naftowymi. Lex petrolea obejmuje szerokie spektrum prawa międzynarodowego, korespondujące ze znaczeniem samego przemysłu naftowego. Można podjąć próbę opisania tego reżimu z dwóch perspektyw: jako zastosowanie prawa międzynarodowego do stanów prawnych z zakresu sektora naftowego lub jako szczególny reżim prawny, który powstał, aby sprostać specyficznym potrzebom sektora ropy i gazu. Z pierwszej perspektywy lex petrolea dotyczy problematyki granic terytorialnych, praw człowieka i prawa środowiska, z drugiej zaś - kluczowe są zagadnienia dotyczące międzynarodowych transakcji handlowych i inwestycji państwowych ${ }^{8}$.

Lex petrolea uznaje władztwo państwa nad zasobami naturalnymi. Czerpanie z nich korzyści wymaga jednak w praktyce zaangażowania prywatnych przedsiębiorstw o znaczącym potencjale kapitałowym, przy czym często sa to prywatne podmioty zagraniczne, tworzące spółki joint venture. Stosunek prawny powstaje tu zatem pomiędzy jednym lub kilkoma przedsiębiorcami a państwem bądź podmiotem publicznym pozostajacym pod nadzorem państwa. Niemniej państwo nie działa tu jedynie jak podmiot prawa prywatnego, gdyż może żądać zrewidowania treści umowy lub nawet ją wypowiedzieć, powołując się na interes publiczny. Udział państwa wyłącza w tym przypadku prywatny charakter transakcji, jednak nie jest to też relacja publiczna, gdyż nie zawiera się w sferze publicznej ${ }^{9}$. Chociaż orzecznictwo arbitrażowe nie pozostawia wątpliwości, że przedmiotowy stosunek prawny ma charakter kontraktowy ${ }^{10}$, w gruncie rzeczy nie sposób ustalić, czy i w jakim zakresie dotyczy on prawa publicznego bądź prywatnego ${ }^{11}$.

w: E. Bastida, T. Wälde, J. Warden-Fernandez (eds.), International and Comparative Mineral Law and Policy. Trends and Prospects, Kluwer, The Hague 2005, s. 227.

${ }^{8}$ Por. T. Martin, Lex petrolea in the international oil and gas industry, w: R. King, Dispute Resolution in the Energy Sector: A Practitioner's Handbook, Globe Law and Business, London 2012, s. 16.

${ }^{9}$ Więcej na ten temat: P. Mayer, La neutralisation du pouvoir normatif de l'État en matière de contrats d'État, „Journal du Droit International” 1986, nr 5, s. 113.

${ }_{10}$ Tak stwierdzono w trzech orzeczeniach arbitrażowych, wielokrotnie przytaczanych w doktrynie: British Petroleum Company (Libya) Limited v. Rzqd Libijskiej Republiki Arabskiej, orzeczenie z 10 października 1973 r., „International Law Reports” 53, 1979, s. 297; Libyan American Oil Company v. Rzqd Libijskiej Republiki Arabskiej, orzeczenie z 12 kwietnia 1977 r. „International Law Materials" 1981, nr 20, s. 89 oraz Texaco Overseas Petroleum Company/ California Asiatic Oil Company v. Rzad Libijskiej Republiki Arabskiej, orzeczenie z 19 stycznia 1977 r., „International Law Reports” 53, 1979, s. 177. Z dwóch ostatnich orzeczeń wynika konkluzja, że „z perspektywy międzynarodowej, koncesja zawsze jest umową. Cyt. za: C. O. García-Castrillón, op. cit., s. 3.

${ }^{11}$ Zdaniem niektórych autorów strona prywatna staje się uczestnikiem prawa publicznego, a jednocześnie podmiotem szczególnych prerogatyw państwowych: C. Turpin, Contracts, w: International Encyclopedia of Comparative Law, Mohr 1982; A. El-Kosheri, T. Riad, The law 
Elementy prawa prywatnego wynikają z kontraktowego charakteru działalności naftowej, natomiast elementy prawa publicznego sa konsekwencja kontrolowania przez państwo produkcji i dostaw oraz wprowadzania przez nie regulacji dotyczacych m.in. zdrowia i bezpieczeństwa publicznego. Lex petrolea nie sprowadza się więc ani do tradycyjnego prawa umów, ani do tradycyjnego międzynarodowego prawa prywatnego, ani też do państwowego prawa pozytywnego. Podczas gdy prawo umów w tradycyjnym ujęciu odnosi się raczej do umów krótkoterminowych, służących wymianie dóbr i usług, $\mathrm{w}$ tym przypadku jednak mamy do czynienia z długoterminowymi stosunkami umownymi cechującymi się szczególnym podejściem do zasady pacta sunt servanda i koncepcji nienaruszalności umów. Podczas gdy międzynarodowe prawo prywatne w tradycyjnym ujęciu sprowadza się do ustalenia metod wyboru właściwych norm kolizyjnych, lex petrolea odrzuca respektowanie granic państwowych i stosowanie norm krajowych do międzynarodowych stosunków prawnych. Natomiast idea pozytywizmu prawniczego, zwłaszcza w klasycznym, Kelsenowskim ujęciu, zastąpiona jest koncepcją otwartości na uznawanie ważności norm utworzonych przez podmioty niepaństwowe, takie jak np. międzynarodowe stowarzyszenia naftowe ${ }^{12}$.

Wszystkie działania związane z przemysłem naftowym, a więc zarówno upstream polegajacy na eksploracji i wydobyciu, a następnie sprzedaży pozyskanego surowca, midstream oznaczajacy przechowywanie surowca i jego transport, jak i downstream obejmujący rafinację i produkcję petrochemiczna, są oparte na umowach. Ograniczona terytorialnie lokalizacja złóż przy jednoczesnym globalnym zapotrzebowaniu na produkt sprawiaja, że są to zazwyczaj umowy międzynarodowe, których cechą charakterystyczną jest długoterminowość. Długi okres obowiąywania stosunku umownego jest niechybnie związany z koniecznością dokonywania w nim sukcesywnych zmian: niektóre z nich będą skutkiem wystapienia nieprzewidzianych przesłanek, inne jednak wynikną z trudności lub niemożności wykonania umowy przez jedną ze stron lub ze zmiany polityki państwowej, podyktowanej aktualnym interesem publicznym. To z kolei powoduje, że przemysł naftowy może być szczególnie ryzykowny dla zagranicznych przedsiębiorstw. Radą na to jest zapewnienie jak najwyższej stabilności orzeczniczej, opartej na wyodrębnionym, uznanym reżimie prawnym.

governing a new generation of petroleum agreements, „ICSID Review” 1, 1986, nr 2, s. 262-263. Szczególnym przypadkiem jest także działanie przez przedsiębiorstwa pozostające pod kontrolą państwa, por. P. Vareilles-Sommières, A. Fekini, Les nouveaux contrats internationaux d'exploration et de partage de production pétrolière en Libye, „Journal du Droit International” 2009, nr 1, s. 17-19. Odnośnie do kwestii jurysdykcji i norm imperatywnych lex fori, zgodnie z praktyka francuska, która ma wpływ opiniotwórczy, sprawy dotyczące nieważności umowy rozpatrywane są przez sądy cywilne, natomiast gdy chodzi o orzeczenie w sprawie zgodności z normami obligatoryjnymi - właściwe są sądy administracyjne (por. P. Pinsolle, The status of vacated awards in France: the Cour de Cassation Decision in Putrabali, „Arbitration International” 24, 2008, nr 2, s. 277-296).

12 Zob. także: A. de Jesús, op. cit., s. 12 i n. 


\section{KSZTAET NORMATYWNY}

Państwa chcące pozyskać inwestorów dla swoich złóż ropy muszą ustanowić środki, które zagwarantuja tym inwestorom określone uprawnienia i zabezpieczą ich działalność od strony prawnej. Zazwyczaj czynią to w drodze umowy - tzw. host government contract, zawieranej przez suwerena lub krajową spółkę naftową z danym inwestorem, którym zwykle jest międzynarodowa spółka naftowo-gazowa. Znaczna liczba klauzul umownych host government contracts konstruowana jest w oparciu o prawo krajowe lub modelowe umowy zawierane przez państwa opiniotwórcze. Wzory często stosowanych umów, które winny być używane przez wszystkie podmioty obecne na rynku lokalnym, opracowuje np. Wielka Brytania w ramach programu PILOT, będącego wspólnym przedsięwzięciem rządu i przemysłu, pod hasłem Streamlined Commercial Agreements. W ramach programu PILOT utworzono także grupę roboczą Progressing Partnership Working Group (PPWG), która uwzględniając interesy rządu i przemysłu, opracowała niewiążacy kodeks praktyk negocjacyjnych, zorientowany na redukcję kosztów i promowanie dobrych praktyk handlowych ${ }^{13}$. Od host government contracts należy odróżnić umowy zawierane przez podmioty prywatne trudniące się poszukiwaniem i produkcją ropy naftowej (takie jak: Confidentiality Agreement, Letter of Intent, Joint Bidding Agreements, Shareholder Agreements, Marketing Agreement, Lifting Agreement, Unitization Agreement, Farm-in/Farm-out Agreement, Joint Operating Agreement [JOA]). Umowy te cechują się kooperacją między spółkami w celu podziału i zmniejszenia ryzyka oraz dywersyfikacji portfolio produkcji poszczególnych spółek ${ }^{14}$. Międzynarodowe spółki naftowe w znaczącym zakresie opieraja swoje postanowienia umowne na dostępnych wzorach. Host government contracts są natomiast raczej właściwe dla danego państwa, którego motywacjąjest wprawdzie przede wszystkim chęć zwiększenia inwestycji zagranicznych, lecz które jednocześnie musi zważać na czynniki polityczne, czy też protekcjonistyczne i kierować się interesem publicznym. Nie wypracowano dotychczas sensu stricto modelu host government contract, jednak w treści tych umów występują klauzule używane powszechnie w umowach modelowych. Mimo więc, że są to umowy sporządzane z uwzględnieniem szczególnych warunków krajowych, zawieraja podobne klauzule i maja podobną strukturę niezależnie od regionu. Jest to rezultatem powszechnej dostępności wzorców umów, obecności globalnych podmiotów, takich jak Bank Światowy oraz działania na płaszczyźnie ogólnomiędzynarodowej stosunkowo niewielkiej grupy prywatnych doradców prawnych ${ }^{15}$. Przy uwzględnieniu tych zbliżonych modeli w zasadzie każde przedsiębiorstwo naftowe wypracowało własne standardy umowne, tak jak każde państwo przyjęło własne procedury i zasady kontraktowania ${ }^{16}$.

\footnotetext{
${ }^{13}$ Zob. http://www.pilottaskforce.co.uk [dostęp: 26.07.2014].

${ }^{14}$ K. Talus, S. Looper, S. Otillar, op. cit., s. 183.

${ }^{15}$ Ibidem, S. 185.

${ }^{16}$ C. O. García-Castrillón, op. cit., s. 13.
} 
Umowy modelowe sa pochodną ogólnych lub szczególnych zasad, standardów, rekomendacji i wytycznych organizacji międzynarodowych, takich jak Zasady międzynarodowych kontraktów handlowych UNIDROIT ${ }^{17}$, Zasady europejskiego prawa kontraktów (PECL) ${ }^{18}$, a także UN Code of Conduct for Transnational Corporation ${ }^{19}$ oraz UN Global Compact Initiative ${ }^{20}$. Niektóre stowarzyszenia sektorowe, na czele z International Energy Committee of American Corporate Counsel Association oraz Association of International Petroleum Negotiators, opracowują wzorce umów, które również pretenduja do standardu w reżimie naftowym. Wzorce umów International Association of Petroleum Negotiators (AIPN) są uznawane za standard w międzynarodowych transakcjach energetycznych. Należą do nich wzorce umów naftowych i gazowych, m.in.: Farmout Agreements, Accounting Procedures (2004), Unitization and Unit Operating Agreements, Study and Bid Group Agreements (2006), Confidentiality Agreements (2007), Consultant Agreements for Business Development in a Host Country, Lifting Agreements, Data Exchange Agreements, LNG Master Sales Agreements (SPA), Secondment Agreements, Gas Sales Agreements, Service Contracts, Gas Transportation Agreements (2009) oraz nowa wersja wzorca umowy Joint Operating Agreement (2012) ${ }^{21}$. Podstawę tych wszystkich umów stanowi wyspecjalizowana wiedza, a wciąż ewoluujące typy klauzul umownych różnią się od tych występujących w generalnym prawie międzynarodowym, jak i w innych rezimach autonomicznych.

Międzynarodowe umowy naftowe wywodzą się z tradycyjnych umów koncesyjnych, a te $\mathrm{z}$ kolei rozwinęły się w oparciu o umowy zawierane w sektorze wydobywczym do trzech podstawowych typów: umów o podziale zysków, nowoczesnych koncesji oraz umów o obsłudze ryzyka. Stosowane faktycznie nazewnictwo jest wprawdzie różnorodne, jednak niektórzy autorzy wskazuja, że wszystkie międzynarodowe umowy naftowe w $80 \%$ zawierają te same treści zamieszczone pod różnymi nagłówkami ${ }^{22}$. Wyszczególnia się więc często następujące typy umów dotyczących poszukiwania i wydobycia ropy naftowej i gazu: licencje/koncesje, zezwolenia, umowy o świadczenie usług, umowy o uczestnictwo, umowy o podziale wpływów z wydobycia, umowy o współpracy, wspólne umowy operacyjne ${ }^{23}$. Można je również pogrupować według trzech kategorii temporalnych: fazy preakwizycyjnej, obejmującej umowy o poufności,

17 UNIDROIT Principles on international commercial contracts, http://www.unidroit.org/english/principles/contracts/principles2010/blackletter2010-english.pdf [dostęp: 11.08.2014].

${ }_{18}$ European Principles of Contract Law, http://www.jus.uio.no/lm/eu.contract.principles. parts.1.to.3.2002/portrait.pdf [dostęp: 11.08.2014].

19 U.N. Code of Conduct on Transnational Corporations, 23 International Legal Materials 626 (1984), http://www1.umn.edu/humanrts/ataglance/compdftun.html\#fn1 [dostęp: 11.08.2014].

20 Zob. http://www.unglobalcompact.org/ [dostęp: 11.08.2014].

${ }^{21}$ Dostępne dla członków AIPN na: www.aipn.org [dostęp: 9.08.2014]. W przygotowaniu sa kolejne wzorce umów, a te już sporządzone są cyklicznie rewidowane.

${ }_{22}$ M.in.: C. Duval et al., International Petroleum Exploration and Exploitation Agreements: Legal, Economics \& Policy Aspects, New York 2009, s. 53.

${ }^{23}$ Licences/ concessions, authorizations, service agreements, participation agreements, production sharing agreements (PSAs), cooperation agreements, joint operation agreements (JOA); zob. np.: C. O. García-Castrillón, op. cit., s. 5. 
listy intencyjne, protokoły ustaleń, szkice warunków umowy ${ }^{24}$; fazy akwizycyjnej obejmujacej umowy poddzierżawy złoża oraz umowy sprzedaży ${ }^{25}$ oraz fazy operacyjnej obejmujacej m.in. wspólne umowy operacyjne oraz umowy akcjonariuszy ${ }^{26}$.

Szczególną cechą umów z tego obszaru jest ich długoterminowość, a wręcz niekiedy uznaje się je za prototypy umów długoterminowych ${ }^{27}$. W przeciwieństwie do umów krótkoterminowych, nakierowanych na precyzyjną interpretację treści i przestrzeganie ich mocy wiążącej, odwołują się one do innych wartości, uwzględniając długofalową relację gospodarczą pomiędzy stronami i promujacc zachowanie między nimi związku pozwalającego na osiagnięcie obopólnych korzyści z transakcji bieżących, jak i wykreowanie nowych w oparciu o współpracę ${ }^{28}$. Nowoczesne umowy naftowe charakteryzują się ponadto nakładaniem znaczących zobowiązań na inwestorów. Zobowiązania te, określane mianem soft issues, dotyczą np. szkolenia lokalnego personelu, transferu technologicznego, korzystania z towarów i usług lokalnych, ochrony środowiska, a zatem obejmują nie tylko operacje petrochemiczne, lecz również rozwój społeczny i ekonomiczny w tym obszarze. Nie chodzi tu już więc jedynie o konfrontację partykularnych interesów stron umowy, lecz o unię różnych interesów, tworzących nowy, wspólny interes: wykonanie projektu, będącego przedmiotem umowy, czyli wydobycie ropy i przeprowadzenie ewentualnego, szeroko rozumianego procesu produkcyjnego ${ }^{29}$. Ten oto wspólny interes jest czynnikiem spajającym społeczność naftową (societas petroleatorum) ${ }^{30}$, złożoną z podmiotów publicznego i prywatnego prawa krajowego i międzynarodowego zaangażowanych w działalność naftową i mających wspólny cel, jakim jest uczynienie możliwym i dochodowym wydobycie i eksploatację ropy naftowej. Solidarność konieczna do osiagnięcia tego celu wykracza poza interes jednostkowy poszczególnych podmiotów i stanowi fundament istnienia

${ }^{24}$ Confidentiality agreement, letter of intent, memorandum of understanding, heads of agreement.

${ }_{25}$ Farm-out/farm-in agreements, purchase and sale agreements.

${ }^{26}$ Joint operation agreements (JOA), shareholder agreements; K. Talus, S. Looper, S. Otillar, op. cit., s. 183; zob. także: S. Otillar, B. Welmaker, Contract structures for petroleum transactions in Latin America: investment in the petroleum industry through joint ownership, w: R. Colmenter, D. Enríquez (eds.), International Oil and Gas Transactions in Latin America, Instituto Technologico Autonomo de Mexico 2011, s. 42 i n.

27 A. Z. El Chiati, Protection of Investments in the Context of Petroleum Agreements, w: Recueil des Cours, Académie de droit international de la Haye, t. 204, Martinus Nijhoff Publishers, 1988, s. 43, cyt. za: M. Sornarajah, The International Law on Foreign Investment, Cambridge University Press, Cambridge 2010, s. 291.

${ }_{28}$ D. A. Rojas, Colombia - towards a new petroleum contractual regime, „International Law: Revista Colombiana de Derecho Internacional” 2004, nr 3, s. 261. Również na ten temat: C. Duval et al., op. cit., s. 34 i n.

29 A. de Jesús, op. cit., s. 34.

30 Ibidem, s. 39. Wyrażenie zainspirowane terminem societas mercatorum, zaproponowanym przez Philippe'a Kahna, a zaadaptowane przez historyka średniowiecza Armando Torresa od łacińskiego terminu oleator, oznaczającego osobę trudniącą się produkcją oliwy. Societas petroleatorum to - zdaniem autora - społeczność złożona z podmiotów zatrudnionych w branży naftowej, obejmująca głównie producentów ropy naftowej, krajowe i międzynarodowe spółki naftowe oraz, do pewnego stopnia, niektóre korporacje zaangażowane w działalność naftową. 
społeczności naftowej, w której stosunki prawne regulowane są przez lex petrolea.

Praktyka sektora naftowego stanowi istotny czynnik kształtowania lex petrolea, gdyż niezależnie od tego, że jej rozwój bywa podstawą do zmian obowiązujących umów, jest również wprowadzana wprost do wzorców umownych odnośna klauzula, zgodnie z którą do danej umowy stosuje się powszechnie uznane zwyczaje i praktyki międzynarodowego przemysłu chemicznego (,,[...] shall apply the generally accepted customs and usages of the international petroleum industry"). Takie klauzule zawieraja krajowe wzorce umów, m.in. Omanu, Ekwadoru i Kongo ${ }^{31}$. Postanowienia wzorców umów oparte są na doświadczeniach płynących z praktyki obserwowanej w podobnych warunkach i często stanowią punkt wyjścia dalszych negocjacji, co ułatwia zawarty $\mathrm{w}$ nich szereg opcji i postanowień alternatywnych. W innych przypadkach odwołanie do najlepszych praktyk w przemyśle naftowym pojawia się $\mathrm{w}$ prawie krajowym przez nakazanie podejmowania wszelkich działań stosowanych na płaszczyźnie międzynarodowej w sposób bezpieczny i wydajny, uwzględniający racjonalne korzystanie z zasobów i zachowanie środowiska naturalnego ${ }^{32}$.

Nie bez znaczenia dla rozwoju lex petrolea jako całości pozostają skodyfikowane zasady kontraktowania, jak wspomniane już Zasady międzynarodowych kontraktów handlowych UNIDROIT oraz Zasady europejskiego prawa kontraktów (PECL), które mogą być stosowane do kontraktów międzynarodowych, jeśli tak postanowią strony, jeśli strony postanowią o stosowaniu do zawartej między nimi umowy ogólnych zasad prawa, lex mercatoria lub podobnych oraz jeżeli strony nie dokonają wyboru żadnych regulacji mających zastosowanie do zawartej przez nie umowy ${ }^{33}$. Z powyższego wynika, że zastosowanie tych regulacji na potrzeby lex petrolea bądź odrzucenie ich leży ad casum w gestii zaangażowanych podmiotów, zatem pełnią one rolę uzupełniającą ${ }^{34}$.

${ }^{31}$ Zob. http://platformlondon.org/carbonweb/documents/drc/A_Lake_of_Oil_Congo_DRC_Tullow_PLATFORM_May_2010.pdf [dostęp: 2.08.2014].

${ }^{32} \mathrm{~Np}$. brazylijska ustawa naftowa $\mathrm{nr} 9478$ z 6 sierpnia 1997, http://www.anp.gov.br/brasil-rounds/round1/Docs/LDOC01_en.pdf [dostęp: 2.08.2014].

${ }^{33}$ W Preambule do Zasad międzynarodowych kontraktów handlowych UNIDROIT czytamy: „These Principles set forth general rules for international commercial contracts. They shall be applied when the parties have agreed that their contract is governed by them. They may be applied when the parties have agreed that their contract be governed by general principles of law, the lex mercatoria or the like [...]". Podobnie w treści Zasad europejskiego prawa kontraktów, art. 1:101: „(1) These Principles are intended to be applied as general rules of contract law in the European Union/ (2) These Principles will apply when the parties have agreed to incorporate them into their contract or that their contract is to be governed by them/ (3) These Principles may be applied when the parties a) have agreed that their contract is to be governed by 'general principles of law', the 'lex mercatoria' or the like [...]".

${ }^{34}$ Zgodnie z art. 5 Rezolucji Instytutu Prawa Mięzynarodowego z 11 września 1979 r. w sprawie prawa właściwego dla umów między państwem a zagraniczna osoba prywatna (The Proper Law of the Contract in Agreements Between a State and a Foreign Private Person, http://www.idi-iil.org/ idiE/resolutionsE/1979_ath_01_en.PDF, 2014-08-02): „Contracts between a State and a foreign private person shall be subjected to the rules of law chosen by the parties or, failing such a choice, to the rules of law with which the contract has the closest link' (art. 1) and that, 'in the absence of 
Orzecznictwo arbitrażowe jest istotnym źródłem regulacji, gdyż stanowi jednocześnie przyczynę i skutek określonego kształtowania wzorców umów. Co istotne, w społeczności naftowej odchodzi się powoli od zasady poufności wyroków na rzecz transparentności ${ }^{35}$. Orzeczenia są publikowane w przeglądach prawnych: „ICC International Arbitration Court Bulletin”, „ICSID Review Foreign Investment Law Journal” oraz „Journal du Droit International (Clunet)". Ponadto w ostatnich latach opublikowano kilka zbiorów orzecznictwa arbitrażowego, służących zarówno analizie temporalnej ${ }^{36}$, jak i merytorycznej ${ }^{37}$ określonych grup orzeczeń i uwzględniających poszczególne fazy rozwoju lex petrolea, tj. od okresu umów koncesyjnych (orzeczenia: Abu Dhabi, 1951 ${ }^{38}$; Qatar, 195339; Aramco, 1958) ${ }^{40}$, poprzez tzw. okres konfrontacyjny, charakteryzujący się poszukiwaniem prawa właściwego (Sapphire v. Iran,1963) ${ }^{41}$ oraz wspomniane już trzy orzeczenia przeciwko Libii: BP (1973), Texaco (1977) i Liamco (1977), aż po nowoczesne międzynarodowe umowy naftowe i związaną z nimi nową generację orzeczeń arbitrażowych w sprawach handlowych i inwestycyjnych. Sama procedura arbitrażowa, mimo postulatów doktrynalnych $^{42}$, nie została jednolicie sformalizowana.

Wszystkie powyższe instrumenty mogą występować w różnych kombinacjach i stanowić zarówno podstawę negocjacji, jak i ich efekt, a brak legitymacji państwowej implikuje niemożność wyszczególnienia kategorii hard law oraz soft law wśród przedmiotowych regulacji normatywnych.

Lex petrolea musi jednak respektować normy imperatywne prawa międzynarodowego, m.in. dotyczące ochrony praw człowieka oraz troski o środowisko

choice by the parties the proper law of the contract shall be derived from indications of the closest connection of the contract".

${ }^{35}$ Jako egzemplifikację tego trendu A. de Jesús podaje nieomal natychmiastową publikację w Internecie orzeczeń arbitrażowych Międzynarodowej Izby Handlowej w sprawach: Mobil Cerro Negro, LTD v. Petróleos de Venezuela and PDVSA Cerro Negro, S.A. z 23 grudnia 2011 r. (ICC 15416/JRF/CA, http://settysoutham.files.wordpress.com/2012/11/award-complete.pdf [dostęp: 1.08.2014] oraz Phillips Petroleum Company Venezuela Limited $i$ ConocoPhillips Petrozuata B.V. v. Petróleos de Venezuela, S.A. z 17 września 2012 r. (ICC 16848/JRF/CA i 16849/JRF, http:// www.google.com/url?sa=t\&rct=j\&q=\&esrc=s\&source=web\&cd=1\&ved=0CB4QFjAA\&url=http $\% 3 \mathrm{~A} \% 2 \mathrm{~F} \% 2 \mathrm{Fwww}$.iareporter.com\%2Fdownloads\%2F20120924\%2Fdownload\&ei=FbjbU_eKOo 6M7Aabv4GwAQ\&usg=AFQjCNFqIZHg-lJyQjTuj-_cHDcORf1Gnw\&bvm=bv.72197243,d.ZGU [dostęp: 1.08.2014]). Jest to jednak w dalszym ciagu pewien trend, a nie powszechna praktyka.

${ }^{36}$ Np. T. Childs, op. cit., s. 214 i n.

${ }^{37} \mathrm{~Np}$. A. El-Kosheri, International arbitration and petroleum contracts, w: Encyclopedia of Hydrocarbons, Rome 2009, s. 879 i n.

38 Petroleum Development (Trucial Coast) Ltd. v. Sheikh of Abu Dhabi (1951), orzeczenie z 14 sierpnia 1951 r., „International Law Reports” 1951, nr 18, s. 144.

${ }^{39}$ Emir Kataru v. International Marine Oil Company Limited, orzeczenie z 12 czerwca 1953 r., „International Law Reports” 1953, nr 20, s. 534.

${ }^{40}$ Arabia Saudyjska v. Arabian American Oil Company (Aramco), orzeczenie z 23 sierpnia 1958 r., „International Law Reports” 1958, nr 27, s. 117.

41 Sapphire International Petroleum v. National Iranian Oil Co., orzeczenie z 15 marca 1963 r., „International Law Reports” 1963, nr 35, s. 136.

${ }^{42}$ Por. L. E. Cuervo, OPEC from myth to reality, „Houston Journal of International Law” 2008, nr 30, s. 535. Zdaniem autora takie wzmocnienie konstrukcji lex petrolea przyczyniłoby się do poprawy współpracy międzynarodowej w sektorze inwestycji. 
naturalne ${ }^{43}$. W obszarze lex petrolea występują również krajowe normy imperatywne stosowane do umów naftowych, które muszą być uwzględniane przez sądy krajowe, jak również przez sądy państw trzecich lub sądy arbitrażowe ${ }^{44}$. Dotycza one m.in. tworzenia przedsiębiorstw, ich ewentualnego udziału w zamówieniach publicznych, spraw fiskalnych, ochrony środowiska, a także dostępu do rynku i reguł konkurencji. Niektóre normy międzynarodowego prawa prywatnego ze skutkiem dla umów naftowych zyskały również moc imperatywną i z uwagi na ryzyko poniesienia odpowiedzialności międzynarodowej przez państwo muszą być przestrzegane przez sądy krajowe. Są to w szczególności regulacje odnoszace się do własności nad zasobami naturalnymi oraz warunków nacjonalizacji i wywłaszczenia ${ }^{45}$.

W rezolucjach Zgromadzenia Ogólnego ONZ dotyczących eksploatacji i praw suwerennych do krajowych zasobów naturalnych stwierdzono, że państwom przysługuje suwerenne władztwo i stałe prawo do swobodnego dysponowania swoimi zasobami i bogactwami naturalnymi zgodnie ze swoim interesem, z korzyścia dla rozwoju narodowego oraz dla dobra narodu. Rezolucje te zarówno w doktrynie, jak i w orzecznictwie arbitrażowym uznawane sa za zwyczaj międzynarodowy i mają zastosowanie do omawianego obszaru merytorycznego ${ }^{46}$.

\section{WNIOSKI}

Dla umożliwienia efektywnego poszukiwania i wydobycia ropy naftowej nie wystarczyłoby bieżące usuwanie problemów prawnych. Konieczne jest istnienie autonomicznego reżimu, który pozwoli zainteresowanym podmiotom, zarówno publicznym, jak i prywatnym, funkcjonować w poczuciu stabilności.

${ }^{43}$ C. O. García-Castrillón, op. cit., s. 18 n.

${ }^{44}$ Por. rozporządzenie Parlamentu Europejskiego i Rady (WE) nr 593/2008 w sprawie prawa właściwego dla zobowiązań umownych (Rzym I), Dz. Urz. L 177/6, art. 9.3: „Można przyznać skuteczność przepisom wymuszającym swoje zastosowanie państwa, w którym ma nastapić lub nastąpiło wykonanie zobowiązań wynikających z umowy, w zakresie, w jakim przepisy te powoduja, że wykonanie umowy jest niezgodne z prawem. Rozważając przyznanie skuteczności takim przepisom, uwzględnia się ich charakter i cel oraz skutki ich zastosowania lub niezastosowania".

${ }^{45} \mathrm{~W}$ orzeczeniu $A M O C O$ zdefiniowano to jako „przymusowy transfer prawa własności”, $A M O$ CO International Finance Corporation v. Islamska Republika Iranu, orzeczenie z 14 lipca 1987 r., „International Legal Materials” 1988, nr 27, s. 189, pkt 220, http://www.trans-lex.org/231900 [dostęp: 2.08.2014].

${ }^{46}$ Zob.: Right to exploit freely natural wealth and resources, 21 grudnia 1952 r., 7 United Nations General Assembly Official Records, supl. nr 20, s. 18; United Nations Documentation $\mathrm{A} / 2361$; Concerted action in favour of economic development of economically less developed countries, 15 grudnia 1960 r.; 15 United Nations General Assembly Official Records, supl. nr 16, s. 9; United Nations Documentation A/4648; Permanent sovereignty over natural resources, 14 grudnia 1962 r.; 17 United Nations General Assembly Official Records, supl. nr 17, s. 15; United Nations Documentation A/5217; Charter of States' economic rights and duties, 12 grudnia $1974 \mathrm{r}$. ; 29 United Nations General Assembly Official Records, supl. nr 31, s. 50; United Nations Documentation A/9631; por. Z. Al Qurashi, International Oil and Gas Arbitration, „Oil, Gas \& Energy Law (OGEL)" Special Study, t. III, 2005, s. 7. 
Orzecznictwo arbitrażowe, standardy dobrych praktyk, prawo krajowe i międzynarodowe stosowane sa jako symultaniczna, skoordynowana sieć regulacji, wykraczając poza klasyczne prawo umów charakteryzujące się konkurencja interesów.

Zgodnie z Raportem Grupy Roboczej Komisji Prawa Międzynarodowego ${ }^{47}$ określone grupy norm i zasad dotyczących szczególnego przedmiotu moga tworzyć reżimy szczególne (self-contained regime) i być stosowane jako lex specialis względem ogólnych norm prawa międzynarodowego ${ }^{48}$. Takie reżimy szczególne często posiadają własne instytucje zarządzające, jednak nie jest to konieczne do uznania ich za reżim szczególny ${ }^{49}$. Odnośnie do lex petrolea można wprawdzie wskazać poszczególne stowarzyszenia międzynarodowe, jednak nie jest możliwe wskazanie jednego organu zarządzającego. Wynika to zapewne z omówionego powyżej charakteru całego reżimu i ratio jego istnienia - jest to instrument odpowiadający założeniom umożliwienia wszystkim podmiotom zyskownego poszukiwania i wydobycia ropy w drodze realizacji ich unii interesów. Tym samym jego pierwszeństwo wobec ogólnych norm prawa międzynarodowego jest uzasadnione tym, że jako lex specialis lepiej odpowiada szczególnemu kontekstowi, w którym jest stosowany, oferując bardziej sprawiedliwy podział dóbr i lepiej oddajacc intencje podmiotów prawnych. Reżim ten może być stosowany do objaśniania, modyfikowania i derogowania norm dyspozytywnych prawa generalnego, jednak jak wskazano powyżej, nie wywiera wpływu na normy imperatywne, a ogólne normy prawa międzynarodowego pozostają ważne i są stosowane w sytuacjach nieprzewidzianych przez ten reżim ${ }^{50}$.

W Raporcie rozróżniono trzy typy reżimów szczególnych ${ }^{51}$, spośród których dwa znajdą odniesienie do lex petrolea. Pierwszy z nich kształtowany jest grupą norm szczególnych, w tym praw i zobowiązań, odnoszących się do szczególnej materii. Normy te mogą wynikać z jednego traktatu, kilku traktatów albo traktatu lub traktatów w połączeniu z odpowiednią praktyką lub prawem zwyczajowym. Drugi typ sprowadza się do zebrania wszystkich zasad i norm regulujacych dany problem prawny tak, aby powstał reżim szczególny, objęty szerszym pojęciem (np. prawo morza, prawo humanitarne, prawa człowieka) i dla celów interpretacyjnych uznany za jedna całość. Lex petrolea znajduje się na pograniczu tych dwóch typów. Z jednej strony charakterystyczne dla

${ }^{47}$ International Law Commission, Report on the work of its fifty-eighth session (1 May to 9 June and 3 July to 11 August 2006), Chapter XII "Fragmentation of international law: difficulties arising from the diversification and expansion of international law", General Assembly, Official Records, Sixty-first Session, supl. nr 10 (A/61/10), http://legal.un.org/ilc/reports/2006/2006report. htm [dostęp: 31.07.2014].

${ }^{48}$ Nie ma przyjętej definicji „ogólnych norm prawa międzynarodowego”. Dla celów niniejszych wniosków wystarczające jest określenie, co jest „ogólne” poprzez odniesienie do logicznego przeciwieństwa, czyli tego, co jest „szczególne”. W praktyce prawniczej rozróżnienie następuje zazwyczaj w odniesieniu do kontekstu, w którym występuja dane normy. Zob. ibidem, pkt 251 (10). Podobnie w tej kwestii: B. Simma, D. Pulkowski, Of planets and the Universe: self-contained regimes in international law, „The European Journal of International Law” 17(3), 2006, s. 487 i n.

${ }^{49}$ Por. ibidem, pkt 251 (11).

${ }^{50}$ Por. ibidem, pkt 251 (7-9)

${ }^{51}$ Por. ibidem, pkt 251 (12). 
niej są regulacje umowne określające prawa i obowiązki stron, których rozwój (także ewentualne aneksowanie zawartej uprzednio umowy długoterminowej) wspierany jest orzecznictwem arbitrażowym oraz praktyką społeczności naftowej, a to plasuje lex petrolea $\mathrm{w}$ typie pierwszym. Z drugiej jednak - nie mamy tu do czynienia z jednym bądź też kilkoma traktatami wyznaczającymi ramy rozwoju praktyki i orzecznictwa, lecz z ciagiem umów, podlegających modyfikacjom odpowiadajacym aktualnym potrzebom dostrzeżonym $\mathrm{w}$ praktyce i orzecznictwie, a to z kolei przemawiałoby za zaliczeniem lex petrolea do reżimów drugiego typu. Ten specyficzny sposób kontraktowania spełnia przesłankę „specjalności” reżimu, która polega na szczególnym sposobie wyrażania zunifikowanego celu, przyświecającego wszystkim zaangażowanym podmiotom, czyli umożliwienia wykonywania zyskownej działalności naftowej. Nie jest to system oparty na modelu contract sans loi, gdyż taki model odrzucałby potrzeby i interesy całej społeczności naftowej, zatem nie odpowiadałby naturze stosunków zobowiąaniowych zawieranych w obszarze lex petrolea. Rama prawną nie jest tu jedynie samowystarczalny reżim kontraktowy, pozostający autonomicznym wobec wszelkich reguł i wartości objętych treścią danej umowy. Sędzia arbiter nie jest podmiotem należącym wyłącznie do danego porządku kontraktowego, lecz przeciwnie - podmiotem autonomicznym, mogacym (o ile kontrakt na to pozwala) oprzeć swoje orzeczenie na zasadach nienależących do umowy lub nieautoryzowanych przez strony, a należących właśnie do lex petrolea ${ }^{52}$.

Podobnie interpretacja i stosowanie norm objętych treścia umów naftowych odzwierciedlają ten nadrzędny cel przez położenie nacisku nie tyle na konfrontację interesów stron, ile na osiagnięcie rezultatu najkorzystniejszego z perspektywy celu umowy ${ }^{53}$. Normy z zakresu lex petrolea maja pierwszeństwo stosowania wobec ogólnych norm prawa międzynarodowego ${ }^{54}$. Uzupełniające stosowanie norm ogólnych nie jest jednak wykluczone, jeśli strony tak postanowią lub jeśli nie dokonają wyboru żadnych regulacji mających zastosowanie do zawartej przez nie umowy ${ }^{55}$. Normy ogólne będą stosowane także wtedy, gdy system szczególny upadnie, np. gdy umowa naftowa będaca podstawą sporu wygaśnie lub okaże się nieważna ex tunc ${ }^{56}$. W świetle powyższego lex petrolea spełnia wszystkie cechy autonomicznego reżimu prawnego.

dr Joanna Osiejewicz

Uniwersytet Zielonogórski

j.osiejewicz@wpa.uz.zgora.pl

${ }^{52}$ Zob. np. AAA/ICDR International Rules 2010, International Centre for Dispute Resolution and American Arbitration Association, art. 28(1): „The tribunal shall apply the substantive law(s) or rules of law designated by the parties as applicable to the dispute. Failing such a designation by the parties, the tribunal shall apply such law(s) or rules of law as it determines to be appropriate", https://www.adr.org/aaa/ShowProperty?nodeId=/UCM/ADRSTG_002037 [dostęp: 7.08.2014].

${ }^{53}$ International Law Commission, Report..., pkt 13.

${ }^{54}$ Por. ibidem, pkt 251(14).

${ }_{55}$ Por. ibidem, pkt 251(15).

${ }^{56}$ Por. ibidem, pkt 251(16). 
LEX PETROLEA AS AN AUTONOMOUS LEGAL REGIME OF INTERNATIONAL LAW

\section{Sum mary}

The specific branch lex petrolea evolved from the national and international doctrine, national laws governing the energy sector, oil contracts, case law, and the practice of entities operating in the oil industry. Both, the internationalisation processes and the solutions to particular problems in this sector, are very similar worldwide and tend to follow the international rather than national trend. The world doctrine, however, is struggling with a lack of universal agreement on the recognition or non-recognition of lex petrolea as a separate legal regime. The aim of this article is to organise knowledge in this field by analysing the output of the doctrine of international law, contracts to perform actions in the petroleum sector, of relevant decisions of arbitration courts and practices of actors involved. After determining the essence of lex petrolea and its normative shape, the results of the analysis were compared with the assumptions made in the Report of the Working Group of the International Law Commission which proposed criteria for the recognition of a group of norms from a specific substantive scope as a self-contained regime and its application as a lex specialis. Thus the hypothesis that lex petrolea is a self-contained regime has been confirmed. 
